\title{
In Memoriam: Dr. med. Eloy Cárdenas Estrada
}

\author{
Carlos E. Medina-De la Garza* \\ Department of Immunology, “Dr. Jose Eleuterio Gonzalez”University Hospital and Center for Research and Development in Health Sciences, CIDICS, \\ Autonomous University of Nuevo Leon, Monterrey, Nuevo Leon, Mexico
}

Christmas Eve 2017, we visited Prof. Eloy Cárdenas in his hospital room, where he received medical treatment for an inflammatory heart disease which affected him early that year. In the middle of our conversation, Eloy asked me something surprising and alarming altogether: to write his necrology for Medicina Universitaria, where he was statistical reviewer and advisor. I assured him I would. "However, I said - it will take long time for that to happen, you will not die anytime soon fellow." Sadly, just about 3 months afterward, Eloy proved right and died in his sleep on Good Friday, March 30th, 2018.

Eloy Cárdenas-Estrada (Fig. 1) was born to Mr. Francisco Cárdenas-Treviño and Mrs. Graciela Estrada Allen in Monterrey in 1952. He spent his childhood in La Purísima neighborhood, in downtown Monterrey. He attended Franco Mexicano school with the Marist Brothers and later on high school, "Preparatoria 2," already part of the Autonomous University of Nuevo Leon (UANL). He studied Medicine from 1969 to 1975 at UANL, where he was an above average student, a playful spirit, quick with a joke and oriented to sports, playing football (left guard, number 74) with the school team Víboras (snakes).

Later, Eloy specialized in Sports Medicine at the University of Münster (West Germany then) and received a scholarship from DAAD (German Academic Exchange Service) to perform doctoral studies there. Besides receiving his doctoral degree through his dissertation, he presented a work to achieve the German habilitation, that is, an authorization to teach medicine in a German University. Upon his return to
Monterrey and the UANL, he was appointed to open and start the Department of Sports Medicine and was its first head (1983-1987). Later on, he would help to establish a similar facility at Universidad Autónoma del Estado de México. He moved to Mexico City to further develop his interest in sports medicine and was an active player in the National Commission of Sports of Mexico and later on, president of the Mexican Federation of Sports Medicine. Eloy was an active member and supporter of different associations and commissions dealing with sports medicine in Mexico and abroad. As a physician, he provided medical care of Mexican athletes in different competitions: he was medical officer at the Barcelona 1992 Summer Olympic Games and also in Pan American, Central American, and University games. Some colleagues grant Eloy's contribution to Mexican sports medicine a key role regarding his innovative vision and consider his endeavor and performance as a turning point. He brought and introduced new approaches and research procedures from Germany into Mexican sports medicine. Eloy was a proactive, assertive individual and his direct, sometimes temperamental style and personality may have harvested some resistance and disagreement in many individuals who met him. As for myself, in our work together at the Center for Research and Development in Health Sciences (CIDICS for its acronym in Spanish) can only confirm that his qualities as a loyal, tireless, knowledgeable, and enthusiastic collaborator, surpassed by far many other of his character traits.

\section{Correspondence:}

${ }^{*}$ Carlos E. Medina-De-la-Garza

E-mail: carlos.medina@uanl.mx
Available online: $27-05-2019$

Date of reception: 22-11-2018

Date of acceptance: 18-12-2018

DOI: 10.24875/RMU.M19000028
Medicina Universitaria. 2019;21(1):36-37 www.medicinauniversitaria.org

5-5796/@ 2018 Universidad Autónoma de Nuevo León. Published by Permanyer México SA de CV. This is an open access article under the CC BY-NC-ND license (http://creativecommons.org/licenses/by-nc-nd/4.0/). 


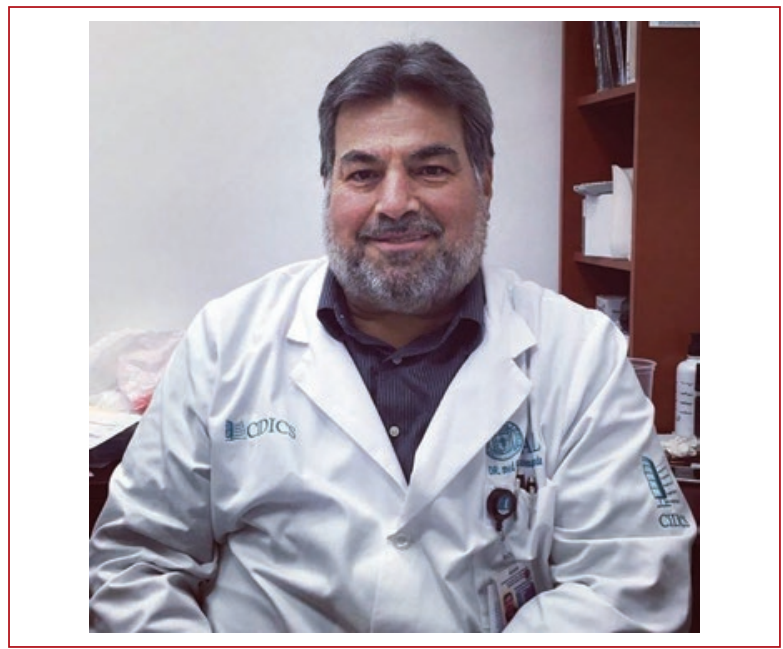

Figure 1. Dr. med. Eloy Cárdenas-Estrada.

As an individual, Eloy's interests were multiple and had an informed point of view for almost everything, ranging from the lightness of cinema world to depths of international politics. His interest for history and distinctively about World War II led us to long conversations about this episode. He had a deep admiration for some German military leaders of the time, i.e., Hans Guderian or Günther Prien and his daring action with U-47 in Scapa Flow. He loved music and had a devotion for the Beatles: he knew all their stories, anecdotes, and songs and played many of them with the guitar. His children (Eloy, orthopedic surgeon, Erik, business manager, and Edwin, engineer) played at his funeral a recording of his favorite "In my life," which was a touching crest at the farewell moment. Eloy also loved the Spanish singer Rocío Dúrcal and enjoyed The Seekers and Judy Durham singing "I'll never find another you". He too appreciated the music of the local Band "Los Reno", a pop assembly from the late 60s. His favorite quote while in German-speaking company was the verse from a song by Drafi Deutscher "Marmor,
Stein und Eisen bricht aber unsere Liebe nicht" (Marble, rocks, and iron break, only our love remains) which he frequently used in suitable (and unsuitable) occasions. He would readily sing or hum radio jingles or TV advertising songs he learned while his stay in Germany, a country he loved.

Eloy developed a deep, working interest in clinical trials and bioethics and had an expertise in biostatistics. He taught this subject to graduate students and residents at our "Dr. JE Gonzalez" University Hospital along with scientific methodology and science philosophy. He was considered an authority on these fields, and he always gladly helped other colleagues and residents on the statistics of their doctoral theses. His work in clinical research evolved in a broad knowledge of legislation in the subject and his collaboration was key in the establishment of working regulations for the newly opened CIDICS in 2010 and its relations with regulatory agencies. He led there the Unit for Bioethics and was president of the Ethics Committee. From there, he made a number of proposals including those regarding the introduction of a living will in our state. Always proposing new ideas and projects, and enthusiastic to use newest technologies available, Eloy started an internet podcast in Bioethics called bioetica-radiotv, which was the first in our institution dedicated to spreading information and knowledge about bioethical issues to both professionals and lay public. He was a loyal and supportive professor of his alma mater, where the School of Sport Sciences (FOD) was his core teaching appointment for over 20 years until his death. His private patients and those attending the clinic for University staff undergoing rehabilitation will remember his good medical care and his charm.

Such was Eloy's life, devoted to his University and his ideals. We will remember him that way: to our great sorrow, his wish for an obituary in these pages is fulfilled. So long Eloy. May you rest in peace. 